\title{
Methylsiloxanes in children silicone-containing products from China: Profiles, leaching, and children exposure
}

\author{
Lin Xu ${ }^{\mathrm{a}}$, Liqin Zhi ${ }^{\mathrm{a}, \mathrm{b}}$, Yaqi Cai ${ }^{\mathrm{a}, \mathrm{b}, \mathrm{c}, *}$ \\ a State Key Laboratory of Environmental Chemistry and Ecotoxicology, Research Center for Eco-Environmental Science, Chinese Academy of Sciences, Beijing 100085, China \\ ${ }^{\mathrm{b}}$ University of Chinese Academy of Sciences, Beijing 100049, China \\ c Institute of Environment and Health, Jianghan University, Wuhan 430056, China
}

\section{A R T I C L E I N F O}

Article history:

Received 30 September 2016

Received in revised form 17 December 2016

Accepted 31 January 2017

Available online 8 February 2017

\section{Keywords:}

Methylsiloxane

Children silicone-containing product

Leaching test

Mouthing exposure

\begin{abstract}
A B S T R A C T
Methylsiloxanes (D4-D6, L5-L16) were detected in children silicone-containing products ( $\mathrm{n}=190$, detected frequencies $=46-89 \%$ ) marketed in China. For the 15 target compounds, the average concentrations ranged from $<\mathrm{LOQ}-0.005 \pm 0.007 \mu \mathrm{g} / \mathrm{g}$ in hard toys, $0.084 \pm 0.281-22.2 \pm 29.6 \mu \mathrm{g} / \mathrm{g}$ in pacifiers, $0.020 \pm 0.023-20.6 \pm$ $16.0 \mu \mathrm{g} / \mathrm{g}$ in teethers, and $0.005 \pm 0.009-2.81 \pm 3.22 \mu \mathrm{g} / \mathrm{g}$ in soft rubber toys. Linear methylsiloxanes were predominant in these four types of children products. In the leaching test, except for L6, the other 14 methylsiloxanes were detected (mean $=0.001 \pm 0.008-0.770 \pm 2.60 \mathrm{ng} / \mathrm{mL}$ ) in saliva leachates for children products, with the detection frequencies ranging from 4 to $46 \%$. The conservative mouthing exposure for children were 6.87$18.05 \mathrm{ng} / \mathrm{kg}$ bw-day via pacifiers and $0.44-2.29 \mathrm{ng} / \mathrm{kg}$ bw-day via teether/soft rubber toys for $\sum$ cyclic methylsiloxanes, and 7.89-20.74 ng/kg bw-day via pacifiers and 0.41-2.12 ng/kg bw-day via teether/soft rubber toys for $\sum$ linear methylsiloxanes. Methylsiloxanes conservative mouthing exposure associated with children products were 1-2 order of magnitudes lower than the sum of children's daily inhalation exposure and dust ingestion exposure in the indoor environment. The above results indicated that although methylsiloxanes, as the impurities of polydimethylsiloxane, distributed in children silicone-containing products, exposure arising from directly mouthing these products may not be the dominated pathway for children exposure of methylsiloxanes.
\end{abstract} (c) 2017 Elsevier Ltd. All rights reserved.

\section{Introduction}

Methylsiloxanes, one of the most important oligomeric species in organosilicon compounds, are predominantly comprised of a backbone of repeating $-\mathrm{Si}\left(\mathrm{CH}_{3}\right)_{2}-\mathrm{O}$-units, which can be divided into two major groups, cyclic methylsiloxanes (D) and linear methylsiloxanes (L). Because of the distinct physicochemical characteristics of these compounds, such as high stability, surface activity, biocompatibility, and lubrication performance, methylsiloxanes have been widely used in many industrial processes and consumer products since the 1940s (Hunter et al., 1946; Horii and Kannan, 2008). Due to its substantial production and extremely wide range of applications, octamethylcyclotetrasiloxane (D4), decamethylcyclopentasiloxane (D5), and dodecamethylcyclohexasiloxane (D6) have been categorized as "high production volume (HPV) chemicals" by the US Environmental Protection Agency and the Organization for Economic Cooperation and Development (Dudzina et al., 2014).

Abbreviations: $\sum$ siloxane, sum of three cyclic and 12 linear methylsiloxanes analyzed; $\sum$ CMS, total concentrations of cyclic methyl siloxanes; $\sum$ LMS, total concentrations of linear methyl siloxanes; PCPs, personal care products.

* Corresponding author at: State Key Laboratory of Environmental Chemistry and Ecotoxicology, Research Center for Eco-Environmental Science, Chinese Academy of Sciences, Beijing 100085, China.

E-mail address: caiyaqi@rcees.ac.cn (Y. Cai).
Recently, methylsiloxanes have been found in a variety of environmental sources, including surface water (Sparham et al., 2008; Zhang et al., 2011), ambient air (Xu et al., 2015; Buser et al., 2013; Xu et al., 2012; McLachlan et al., 2010; Warner et al., 2010), indoor air and dust (Tran et al., 2015; Tran and Kannan, 2015; Pieri et al., 2013; Lu et al., 2010), sediment (Wang et al., 2013; Zhang et al., 2011), sewage sludge (Lee et al., 2014; Bletsou et al., 2013), biota (Jia et al., 2015; McGoldrick et al., 2014) and human plasma (Xu et al., 2015), and even in remote regions (Sanchis et al., 2015). For adults, dermal and inhalation were the main exposure pathways of methylsiloxanes, with exposure rates three orders of magnitudes higher than those through dust ingestion (Xu et al., 2012; Lu et al., 2010; Lu et al., 2011; Tran and Kannan, 2015). However, besides inhalation, dust ingestion, and dermal contact, children/infants may have unique exposure pathways of chemicals because their behavioral characteristics are different from those of adults. For example, Zhang et al. (2012) and Horii and Kannan (2008) detected cyclic (D4-D6) and linear (L4-L14) methylsiloxanes in some children products (pacifier/nipples and bakewares) from USA, with concentrations ranging from $0.2-7030 \mu \mathrm{g} / \mathrm{g}$, indicating that children silicone-containing products (such as non-nutritive sucking/chewing pacifier/ nipples, teethers and toys, etc.) may be potential exposure sources of methylsiloxanes. Furthermore, children might be different from adults in their vulnerability and susceptibility due to the immaturity of 
metabolic systems and clearance mechanisms, which may lead to longer half-lives of environmental contaminants (Clewell et al., 2004; Ginsberg et al., 2002). Therefore, exposure to chemicals in the pediatric population deserves specially dedicated attention and study. Owing to their thermal stabilities and physiochemical inertness, silicone polymers, especially polydimethylsiloxane (PDMS) can be used to manufacture siliconized rubber products for children, such as pacifiers, teethers, cookware, and rubber toys. As impurities of PDMS, methylsiloxanes might be released from these products into the ambient environment during use. More importantly, with respect to young children, especially those between 3 and 36 months old, direct ingestion of methylsiloxanes in children products would be a potentially significant exposure pathway. To the best of our knowledge, there have been no systematic studies on the exposure to methyl siloxanes in the pediatric population as associated with children silicone-containing products.

In the present study, we investigated the distribution of methylsiloxanes in various children silicone-containing products (pacifiers, teethers, hard toys, and soft rubber toys) made in China, and explored their leaching from children silicone-containing products in artificial saliva. Additionally, the exposure levels of children to methylsiloxanes via children silicone-containing products were also calculated.

\section{Materials and methods}

\subsection{Sample collection}

A total of 190 children products, which contained silicone components reported by their commercial specifications, were collected from 30 supermarkets in fifteen cities in China. They were divided into four groups: hard toys $(n=40)$, pacifiers $(n=74)$, teethers $(n=32)$, and soft rubber toys $(n=44)$.

\subsection{Materials}

Individual standard cyclic siloxanes (D4, D5, D6) and linear siloxanes [polydimethylsiloxane mixture (PDMS)], as well as an internal standard, tetrakis(trimethylsiloxy)silane (M4Q) were purchased from Sigma-Aldrich (St. Louis, MO, USA). Details of the composition of the PDMS mixture are described in the supporting materials (Table S1). nHexane was obtained from Fisher Scientific (Fair Lawn, New Jersey, USA). The chemicals used in the preparation of artificial saliva came from Sinopharm Chemical Reagent Co. Ltd. (Shanghai, China). Ultrapure water was prepared by using a Milli-Q water purification system (Millipore, Bedford, MA, USA).

\subsection{Sample preparation}

In order to eliminate external contamination, the samples were precleaned with ultrapure water and air-dried at room temperature. Several pieces of matrix were broken off from the main body of each sample. They were then cut into small fragments with a size of $2 \mathrm{~mm}$ or less by n-hexane cleaned scissors.

\subsubsection{Extraction experiment}

For the analysis of D4-D6 and L5-L16, $1 \mathrm{~g}$ of sample was immersed in $5 \mathrm{~mL}$ of n-hexane in a glass container. The sample was spiked with $100 \mathrm{ng}$ of M4Q and shaken ( $250 \mathrm{rpm}$ ) for $24 \mathrm{~h}$. After sonicating for $10 \mathrm{~min}$, the solvent layer was transferred into a glass tube. Each sample was extracted three times. The second and the third extractions were performed using $3 \mathrm{~mL}$ of n-hexane, shaken for $30 \mathrm{~min}$, and sonicated for $10 \mathrm{~min}$. The extracts were combined and concentrated to $1 \mathrm{~mL}$ under a gentle nitrogen flow before instrumental analysis. Necessary dilutions were performed if the concentrations exceed the linear range of calibration.

\subsubsection{Artificial saliva leaching experiment}

The time-dependent (5-600 min) immersion test in our study was conducted to systematically investigate the migration behaviors (migration capacities and equilibrium time) of methylsiloxanes between silicone-contained children products and saliva. Each sample (about $1 \mathrm{~g}$ ) was immersed in $5 \mathrm{~mL}$ of artificial saliva in a glass container. The artificial saliva was prepared according to a previous literature (Kusu et al., 1998; Niessner and Klampfl, 2000) and the details are provided in supporting information. The containers were filled without headspace and sealed hermetically. Then, they were shaken $(120 \mathrm{rpm})$ for different durations $\left(5,20,40,60,120,240,600 \mathrm{~min}\right.$ ) at $37^{\circ} \mathrm{C}$ (Allami et al., 2010). The target compounds in artificial saliva were extracted by a liquid-liquid extraction (LLE) method as reported in a previous study (Bletsou et al., 2013) with some modifications. In brief, the artificial saliva leachates were transferred into a separatory funnel and spiked with $100 \mathrm{ng}$ of $\mathrm{M} 4 \mathrm{Q}$. Then, the leachates were extracted with $5 \mathrm{~mL}$-hexane three times. Subsequently, the mixture was centrifuged at $3000 \mathrm{rpm}$ for $10 \mathrm{~min}$ and concentrated to $1 \mathrm{~mL}$ as described above for analysis.

\subsection{Chemical analysis}

To analyze cyclic and linear methylsiloxanes, an Agilent 7890A gas chromatograph (GC) equipped with a 5\% phenyl methylsiloxane capillary column (HP-5 ms; $30 \mathrm{~m} \times 0.25 \mathrm{~mm}$ i.d. $\times 0.25 \mu \mathrm{m}$ ) was used for separation. An Agilent 5975C mass spectrometer with an electron impact (EI) ion source in the selected ion monitoring (SIM) mode was used for detection. Helium was used as the carrier gas at a flow rate of $1 \mathrm{~mL} / \mathrm{min}$. For D4-D6, the injector port (splitless mode), ionization source, mass analyzer, and transfer line temperatures were maintained at $200,230,150$ and $280^{\circ} \mathrm{C}$, respectively. Likewise, for L5-L16, the temperatures were maintained at $300,280,150,280^{\circ} \mathrm{C}$, respectively. Table S2 lists the mass-to-charge ratios of the ions used to monitor the signal of each compound.

\subsection{Quality assurance and quality control}

Due to the ubiquitous use of methylsiloxanes in many consumer products and laboratory products, the analyst should take particular care in preventing contamination during sample treatment procedures. Any personal care products containing siloxanes were prohibited in time of sample collection and analysis To minimize background contamination, all of the glass containers were heated to $300{ }^{\circ} \mathrm{C}$ for $4 \mathrm{~h}$ and pre-cleaned with n-hexane before use (Horii and Kannan, 2008; Lu et al., 2010; Bletsou et al., 2013). No silicon-based materials were used. For GC-MS analysis, silicone-based septa in GC vials were replaced with aluminum foil. Instrument blanks and procedural blanks were analyzed in parallel with every set of 5 samples to monitor interferences and cross-contaminations. The concentration found in the procedural blank was subtracted from the concentrations for the samples. When the analyte concentrations exceeded the linear dynamic range of the calibration curve, they were diluted to a proper concentration and requantified. D4, D5, and D6 were detected in procedural blanks at trace levels in children product samples $(0.9-1.7 \mathrm{ng} / \mathrm{g})$ and artificial saliva leachates $(0.01-0.03 \mathrm{ng} / \mathrm{mL})$, whereas linear methylsiloxanes were not observed in procedural blanks. Hence, for D4-D6, the LOQs were defined as 10 times the standard deviation of the procedural blank concentrations $(\mathrm{n}=7)$. For L3-L16, as they were not detected in procedural blanks, LOQs were determined as 10 times the standard deviation of signals of laboratory blank samples $(n=7)$ spiked with known concentrations of the target compounds. LOQs for methylsiloxanes (D4-D6 and L5-L16) were in the range of $0.4-1.4 \mathrm{ng} / \mathrm{g}$ for children products and 0.01-0.06 ng/mL for artificial saliva leachates. Recoveries for children silicone-containing products and artificial saliva leachates were 88$96 \%$ and $81-94 \%$, respectively. The relative standard deviations (RSD, $\%$ ) of methyl siloxanes concentrations in duplicate children siliconecontaining product samples were $<15 \%$. 
In addition, we did some experiments to test the extraction efficiency of children products according to one previous study (Horii and Kannan, 2008). In brief, after the first extraction, the children products were soaked in $5 \mathrm{~mL}$ of $\mathrm{n}$-hexane for $24 \mathrm{~h}$. The first and second extracts were concentrated and analyzed individually. Overall, the concentrations of both cyclic and linear siloxanes measured in second extraction were about $<8 \%$ of their concentrations in the first extraction.

\section{Results and discussion}

\subsection{Concentrations and profiles of methylsiloxanes in children silicone-con- taining products}

\subsubsection{Concentrations of siloxanes in children products}

A summary of quantified concentrations and detection frequencies of three cyclic (D4-D6) and 12 linear siloxanes (L5-L16) in children silicone-containing products are presented in Table 1. Overall, all the analyzed samples $(n=190)$, except for 8 hard toys, contained at least one of the detectable methylsiloxanes. The average concentrations of target methylsiloxanes in all the children silicone-containing products ranged from $0.021-12.7 \mu \mathrm{g} / \mathrm{g}$, with detection frequencies (df) ranging from $46 \%-89 \%$.
The detection frequencies of cyclic siloxanes (D4-D6) were $100 \%$ in the pacifiers/nipples and teethers, while in soft rubber toys and hard toys, the detection frequencies of D4-D6 ranged from 91\%-100\% and $10-50 \%$, respectively. The highest concentrations of D4-D6 were found in teethers (median: $0.136 \mu \mathrm{g} / \mathrm{g}$ for D4, $2.25 \mu \mathrm{g} / \mathrm{g}$ for D5, and $3.63 \mu \mathrm{g} / \mathrm{g}$ for D6, respectively), followed by pacifiers (median: $0.107 \mu \mathrm{g} / \mathrm{g}$ for D4, $0.924 \mu \mathrm{g} / \mathrm{g}$ for D5, and $1.46 \mu \mathrm{g} / \mathrm{g}$ for D6, respectively) and soft rubber toys (median: $0.062 \mu \mathrm{g} / \mathrm{g}$ for D4, $0.086 \mu \mathrm{g} / \mathrm{g}$ for D5, and $0.101 \mu \mathrm{g} / \mathrm{g}$ for D6, respectively). D4 is an important monomer in the manufacture of silicon polymers, whereas D5 and D6, as its rearrangement products, often exist as impurities in silicone products. The concentrations of D4-D6 in hard toys were generally the lowest among the four types of children products, with median values of $0.45 \times 10^{-3} \mu \mathrm{g} / \mathrm{g}$ for D5 and less than the LOQ for D4 and D6. Trace levels of D5 in hard toys might have been found because it is a primary additive in the chemicals used in the production of hard toys. Currently, the systematic studies about methylsiloxanes in children products were scarce. Two previous studies reported several to hundreds times higher concentrations of cyclic methyslioxanes in nipples from USA than those in our study - Zhang et al. (2012) reported the presence of D4-D6 in silicone nipples with concentrations ranging from $0.6-49$ (median $=2.5$, mean $=7.08) \mu \mathrm{g} / \mathrm{g}$ for D4, 0.6-269 (median $=4.6$, mean $=32.7) \mu \mathrm{g} / \mathrm{g}$ for D5, and $0.3-108$ (median $=3.9$, mean $=13.8) \mu \mathrm{g} / \mathrm{g}$ for D6, while

Table 1

Concentrations ( $\mu \mathrm{g} / \mathrm{g}$; max, min, median and mean) and detection frequency (\%) of methylsiloxanes in different children silicone-containing products.

\begin{tabular}{|c|c|c|c|c|c|c|c|c|c|c|c|c|c|c|c|c|}
\hline & & D4 & D5 & D6 & L5 & L6 & L7 & L8 & L9 & L10 & L11 & L12 & L13 & L14 & L15 & L16 \\
\hline \multirow[t]{6}{*}{ Hard toys } & Mean $^{a}$ & $\begin{array}{l}0.49 \times \\
10^{-3}\end{array}$ & 0.002 & 0.002 & $\begin{array}{l}0.05 \times \\
10^{-3}\end{array}$ & $\begin{array}{l}<0.8 \times \\
10^{-3}\end{array}$ & 0.001 & 0.003 & 0.002 & 0.003 & 0.001 & 0.002 & 0.002 & 0.005 & 0.003 & $\begin{array}{l}0.49 \times \\
10^{-3}\end{array}$ \\
\hline & SD & 0.002 & 0.004 & 0.006 & 0.0002 & & 0.005 & 0.005 & 0.003 & 0.005 & 0.003 & 0.003 & 0.005 & 0.007 & 0.005 & 0.003 \\
\hline & Min & $\begin{array}{l}<0.6 \times \\
10^{-3}\end{array}$ & $\begin{array}{l}<0.4 \times \\
10^{-3}\end{array}$ & $\begin{array}{l}<0.7 \times \\
10^{-3}\end{array}$ & $\begin{array}{l}<0.9 \times \\
10^{-3}\end{array}$ & $\begin{array}{l}<0.8 \times \\
10^{-3}\end{array}$ & $\begin{array}{l}<0.9 \times \\
10^{-3}\end{array}$ & $\begin{array}{l}<0.9 \times \\
10^{-3}\end{array}$ & $\begin{array}{l}<0.8 \times \\
10^{-3}\end{array}$ & $\begin{array}{l}<0.9 \times \\
10^{-3}\end{array}$ & $\begin{array}{l}<0.6 \times \\
10^{-3}\end{array}$ & $\begin{array}{l}<0.9 \times \\
10^{-3}\end{array}$ & $\begin{array}{l}<1.1 \times \\
10^{-3}\end{array}$ & $\begin{array}{l}<0.8 \times \\
10^{-3}\end{array}$ & $\begin{array}{l}<0.9 \times \\
10^{-3}\end{array}$ & $\begin{array}{l}<1.4 \times \\
10^{-3}\end{array}$ \\
\hline & Median & $\begin{array}{l}<0.6 \times \\
10^{-3}\end{array}$ & $\begin{array}{l}0.45 \times \\
10^{-3}\end{array}$ & $\begin{array}{l}<0.7 \times \\
10^{-3}\end{array}$ & $\begin{array}{l}<0.9 \times \\
10^{-3}\end{array}$ & $\begin{array}{l}<0.8 \times \\
10^{-3}\end{array}$ & $\begin{array}{l}<0.9 \times \\
10^{-3}\end{array}$ & $\begin{array}{l}<0.9 \times \\
10^{-3}\end{array}$ & $\begin{array}{l}<0.8 \times \\
10^{-3}\end{array}$ & $\begin{array}{l}<0.9 \times \\
10^{-3}\end{array}$ & $\begin{array}{l}<0.6 \times \\
10^{-3}\end{array}$ & $\begin{array}{l}<0.9 \times \\
10^{-3}\end{array}$ & $\begin{array}{l}<1.1 \times \\
10^{-3}\end{array}$ & 0.001 & $\begin{array}{l}<0.9 \times \\
10^{-3}\end{array}$ & $\begin{array}{l}<1.4 \times \\
10^{-3}\end{array}$ \\
\hline & Max & 0.009 & 0.013 & 0.025 & 0.001 & $\begin{array}{l}<0.8 \times \\
10^{-3}\end{array}$ & 0.021 & 0.017 & 0.010 & 0.023 & 0.011 & 0.007 & 0.016 & 0.023 & 0.016 & 0.009 \\
\hline & $\mathrm{df}(\%)$ & 10 & 50 & 40 & 5 & 0 & 20 & 30 & 35 & 35 & 25 & 45 & 30 & 50 & 40 & 10 \\
\hline \multirow[t]{6}{*}{ Pacifiers } & Mean & 1.46 & 3.23 & 5.66 & 0.084 & 0.030 & 1.45 & 2.63 & 0.989 & 4.17 & 5.61 & 4.87 & 5.13 & 9.64 & 22.2 & 12.1 \\
\hline & $\mathrm{SD}$ & 7.38 & 10.9 & 13.3 & 0.281 & 0.039 & 3.62 & 8.58 & 1.02 & 7.23 & 10.8 & 9.79 & 11.1 & 18.1 & 29.6 & 21.7 \\
\hline & Min & 0.012 & 0.031 & 0.062 & $\begin{array}{l}<0.9 \times \\
10^{-3}\end{array}$ & $\begin{array}{l}<0.8 \times \\
10^{-3}\end{array}$ & 0.007 & 0.005 & 0.018 & 0.042 & 0.041 & 0.019 & 0.041 & 0.022 & 0.580 & 0.096 \\
\hline & Median & 0.107 & 0.924 & 1.46 & 0.005 & 0.011 & 0.369 & 0.326 & 0.512 & 1.87 & 1.26 & 1.25 & 1.62 & 2.65 & 7.13 & 4.69 \\
\hline & Max & 45.1 & 66.3 & 74.1 & 1.58 & 0.191 & 20.3 & 51.0 & 3.58 & 31.8 & 39.9 & 43.7 & 66.8 & 97.7 & 106.4 & 121.5 \\
\hline & df (\%) & 100 & 100 & 100 & 70 & 84 & 100 & 100 & 100 & 100 & 100 & 100 & 100 & 100 & 100 & 100 \\
\hline \multirow[t]{6}{*}{ Teethers } & Mean & 0.312 & 3.26 & 4.96 & 0.020 & 0.051 & 2.16 & 5.99 & 5.18 & 6.96 & 10.1 & 9.11 & 9.24 & 9.52 & 20.6 & 18.2 \\
\hline & SD & 0.403 & 2.99 & 4.28 & 0.023 & 0.037 & 2.22 & 6.34 & 4.89 & 7.46 & 13.2 & 9.78 & 6.37 & 6.20 & 16.0 & 12.5 \\
\hline & Min & 0.005 & 0.016 & 0.018 & $\begin{array}{l}<0.9 \times \\
10^{-3}\end{array}$ & $\begin{array}{l}<0.8 \times \\
10^{-3}\end{array}$ & $\begin{array}{l}<0.9 \times \\
10^{-3}\end{array}$ & 0.025 & 0.123 & 0.115 & 0.160 & 0.397 & 0.078 & 0.403 & 0.702 & 0.294 \\
\hline & Median & 0.136 & 2.25 & 3.63 & 0.016 & 0.066 & 1.25 & 2.93 & 2.08 & 6.10 & 3.60 & 4.99 & 6.86 & 8.87 & 13.3 & 14.5 \\
\hline & Max & 1.46 & 10.4 & 16.4 & 0.071 & 0.105 & 8.59 & 18.6 & 14.1 & 30.7 & 42.8 & 40.2 & 22.4 & 23.2 & 63.8 & 37.9 \\
\hline & df (\%) & 100 & 100 & 100 & 75 & 88 & 94 & 100 & 100 & 100 & 100 & 100 & 100 & 100 & 100 & 100 \\
\hline \multirow{6}{*}{$\begin{array}{l}\text { Soft } \\
\text { rubber } \\
\text { toys }\end{array}$} & Mean & 0.143 & 0.515 & 1.24 & 0.007 & 0.005 & 0.202 & 0.482 & 0.357 & 0.891 & 0.151 & 0.694 & 0.591 & 1.04 & 2.81 & 2.31 \\
\hline & SD & 0.205 & 0.866 & 2.26 & 0.016 & 0.009 & 0.518 & 1.26 & 0.989 & 1.87 & 2.83 & 1.95 & 1.28 & 1.39 & 3.22 & 2.37 \\
\hline & Min & 0.030 & $\begin{array}{l}<0.4 \times \\
10^{-3}\end{array}$ & 0.024 & $\begin{array}{l}<0.9 \times \\
10^{-3}\end{array}$ & $\begin{array}{l}<0.8 \times \\
10^{-3}\end{array}$ & $\begin{array}{l}<0.9 \times \\
10^{-3}\end{array}$ & 0.002 & $\begin{array}{l}<0.8 \times \\
10^{-3}\end{array}$ & 0.005 & 0.019 & 0.005 & 0.009 & 0.072 & 0.395 & 0.581 \\
\hline & Median & 0.062 & 0.086 & 0.101 & $\begin{array}{l}<0.9 \times \\
10^{-3}\end{array}$ & 0.001 & 0.035 & 0.225 & 0.105 & 0.101 & 0.400 & 0.396 & 0.195 & 0.597 & 1.84 & 1.79 \\
\hline & Max & 0.969 & 1.93 & 8.55 & 0.055 & 0.017 & 1.37 & 0.68 & 0.900 & 4.82 & 4.74 & 0.659 & 1.06 & 3.44 & 5.84 & 4.58 \\
\hline & $\mathrm{df}(\%)$ & 100 & 91 & 100 & 23 & 55 & 91 & 100 & 82 & 100 & 100 & 100 & 100 & 100 & 100 & 100 \\
\hline \multirow{6}{*}{$\begin{array}{l}\text { All } \\
\text { products }\end{array}$} & Mean & 0.653 & 1.90 & 3.31 & 0.038 & 0.021 & 0.957 & 2.09 & 1.30 & 2.93 & 4.13 & 3.50 & 3.63 & 5.55 & 12.7 & 8.24 \\
\hline & SD & 4.61 & 7.04 & 8.86 & 0.179 & 0.034 & 2.55 & 6.25 & 2.74 & 5.97 & 9.25 & 7.94 & 8.10 & 12.4 & 22.0 & 15.9 \\
\hline & Min & $\begin{array}{l}<0.6 \times \\
10^{-3}\end{array}$ & $\begin{array}{l}<0.4 \times \\
10^{-3}\end{array}$ & $\begin{array}{l}<0.7 \times \\
10^{-3}\end{array}$ & $\begin{array}{l}<0.9 \times \\
10^{-3}\end{array}$ & $\begin{array}{l}<0.8 \times \\
10^{-3}\end{array}$ & $\begin{array}{l}<0.9 \times \\
10^{-3}\end{array}$ & $\begin{array}{l}<0.9 \times \\
10^{-3}\end{array}$ & $\begin{array}{l}<0.8 \times \\
10^{-3}\end{array}$ & $\begin{array}{l}<0.9 \times \\
10^{-3}\end{array}$ & $\begin{array}{l}<0.6 \times \\
10^{-3}\end{array}$ & $\begin{array}{l}<0.9 \times \\
10^{-3}\end{array}$ & $\begin{array}{l}<1.1 \times \\
10^{-3}\end{array}$ & $\begin{array}{l}<0.8 \times \\
10^{-3}\end{array}$ & $\begin{array}{l}<0.9 \times \\
10^{-3}\end{array}$ & $\begin{array}{l}<1.4 \times \\
10^{-3}\end{array}$ \\
\hline & Median & 0.066 & 0.161 & 0.355 & $\begin{array}{l}<0.9 \times \\
10^{-3}\end{array}$ & 0.004 & 0.186 & 0.257 & 2.79 & 0.324 & 0.784 & 0.517 & 0.655 & 1.06 & 2.14 & 1.97 \\
\hline & Max & 45.1 & 66.3 & 74.1 & 1.58 & 0.191 & 20.3 & 51.0 & 14.1 & 31.8 & 42.8 & 43.7 & 66.8 & 97.7 & 106.4 & 121.5 \\
\hline & $\mathrm{df}(\%)$ & 82 & 87 & 87 & 46 & 60 & 80 & 85 & 82 & 86 & 84 & 88 & 85 & 89 & 87 & 87 \\
\hline
\end{tabular}

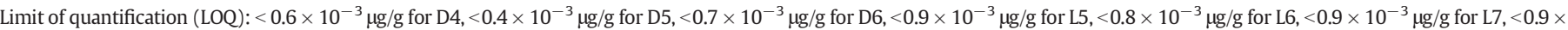

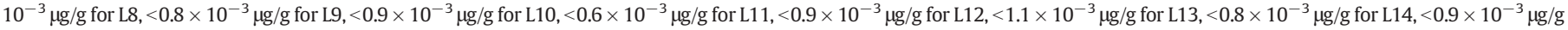
for L15, $<1.4 \times 10^{-3} \mu \mathrm{g} / \mathrm{g}$ for L16.

a Concentrations below LOQ were calculated with $\mathrm{f} \times \mathrm{LOQ}$, with $\mathrm{f}$ being the fraction of samples above LOQ. 
Horii and Kannan (2008) reported that concentrations in nipples were $0.62-0.87($ median $=0.74) \mu \mathrm{g} / \mathrm{g}$ for $\mathrm{D} 4,5.7-159($ median $=80) \mu \mathrm{g} / \mathrm{g}$ for D5, and 12-741 (median = 307) $\mu \mathrm{g} / \mathrm{g}$ for D6.

Among the analyzed linear methylsiloxanes, L7-L16 were more frequently found than L5 and L6. Linear siloxanes, with the exception of L5 ( $\mathrm{df}=70 \%)$ and $\mathrm{L6}(\mathrm{df}=84 \%)$, were detected in all pacifier samples. Their concentrations in pacifier samples, in terms of median values, were present in the following decreasing order: L15 $(7.13 \mu \mathrm{g} / \mathrm{g})>\mathrm{L} 16$ $(4.69 \mu \mathrm{g} / \mathrm{g})>\mathrm{L} 14(2.65 \mu \mathrm{g} / \mathrm{g})>\mathrm{L} 10(1.87 \mu \mathrm{g} / \mathrm{g})>\mathrm{L} 13(1.62 \mu \mathrm{g} / \mathrm{g})>\mathrm{L} 11$ $(1.26 \mu \mathrm{g} / \mathrm{g})>\mathrm{L} 12(1.25 \mu \mathrm{g} / \mathrm{g})>\mathrm{L} 9(0.512 \mu \mathrm{g} / \mathrm{g})>\mathrm{L} 7(0.369 \mu \mathrm{g} / \mathrm{g})>\mathrm{L} 8$ $(0.326 \mu \mathrm{g} / \mathrm{g})>\mathrm{L} 6(0.011 \mu \mathrm{g} / \mathrm{g})>\mathrm{L} 5(0.005 \mu \mathrm{g} / \mathrm{g})$. Zhang et al. (2012) did not detect linear methylsiloxane in pacifier/nipples. However, it should be noted that Zhang et al. (2012) only determined L3-L5 in their previous study, whereas in present study, twelve linear siloxanes were analyzed including L5-L16. In addition, Horii and Kannan (2008) merely reported the concentrations of total linear siloxanes (median = $11 \mu \mathrm{g} / \mathrm{g}$; mean $=14 \mu \mathrm{g} / \mathrm{g}$ ) but not those of individual homologues in pacifier/nipples. In teethers, except for L5-L7 ( $\mathrm{df}=75-94 \%)$, the detection frequencies of all other nine linear methylsiloxanes were $100 \%$. Similar with pacifier samples, L15 and L16 in teethers were detected at the highest concentrations with the median values of $13.3 \mu \mathrm{g} / \mathrm{g}$ and $14.5 \mu \mathrm{g} / \mathrm{g}$, respectively, followed by L14 (median: $8.87 \mu \mathrm{g} / \mathrm{g}$ ) and L13 (median: $6.86 \mu \mathrm{g} / \mathrm{g}$ ). The median concentrations of the other linear siloxanes ranged from $0.016-6.10 \mu \mathrm{g} / \mathrm{g}$ and decreased in the order of L10 $(6.10 \mu \mathrm{g} / \mathrm{g})>\mathrm{L} 12(4.99 \mu \mathrm{g} / \mathrm{g})>\mathrm{L} 11(3.60 \mu \mathrm{g} / \mathrm{g})>\mathrm{L} 8(2.93 \mu \mathrm{g} /$ g) $>$ L9 $(2.08 \mu \mathrm{g} / \mathrm{g})>$ L7 $(1.25 \mu \mathrm{g} / \mathrm{g})>\mathrm{L} 6(0.066 \mu \mathrm{g} / \mathrm{g})>\mathrm{L} 5(0.016 \mu \mathrm{g} /$ $\mathrm{g})$. L8 and L10-L16 were found in all the soft rubber toys, whereas detection frequencies of L5-L7 and L9 ranged from 23\%-91\%. The median concentrations of linear methylsiloxanes in soft rubber toys, ranged from $<\mathrm{LOQ}-1.84 \mu \mathrm{g} / \mathrm{g}$, and were lower than the concentrations in pacifiers $(0.005-7.13 \mu \mathrm{g} / \mathrm{g})$ and teethers $(0.016-14.5 \mu \mathrm{g} / \mathrm{g})$, with a decreased order of L15 $(1.84 \mu \mathrm{g} / \mathrm{g})>\mathrm{L} 16(1.79 \mu \mathrm{g} / \mathrm{g})>\mathrm{L} 14(0.597 \mu \mathrm{g} /$ g) $>$ L11 $(0.400 \mu \mathrm{g} / \mathrm{g})>\operatorname{L} 12(0.396 \mu \mathrm{g} / \mathrm{g})>\mathrm{L} 8(0.225 \mu \mathrm{g} / \mathrm{g})>\mathrm{L} 13$ $(0.195 \mu \mathrm{g} / \mathrm{g})>$ L9 $(0.105 \mu \mathrm{g} / \mathrm{g})>\mathrm{L} 10(0.101 \mu \mathrm{g} / \mathrm{g})>\mathrm{L} 7(0.035 \mu \mathrm{g} /$ $\mathrm{g})>\mathrm{L} 6(0.001 \mu \mathrm{g} / \mathrm{g})$. Compared with those in pacifiers, teethers, and soft rubber toys, linear methylsiloxanes were less frequently found in hard toys. L5-L16 were found in less than half of the hard toys ( $\mathrm{df}=$ $0-50 \%$ ), with concentrations substantially lower than those in the other three categories of children silicone-containing products. The median concentrations of L5-L16 in hard toys ranged from less than the LOQ to $0.001 \mu \mathrm{g} / \mathrm{g}$. The absence of methylsiloxanes in most hard toys samples indicated their infrequent use in these products.

\subsubsection{Profiles of cyclic and linear siloxanes}

Overall, $\sum$ siloxane (sum of three cyclic and 12 linear methylsiloxanes analyzed) in the samples analyzed varied widely. $\sum$ siloxane in pacifiers and teethers were significantly higher by $1-3$ orders of magnitude than those in hard toys and soft rubber toys. Teethers contained the highest $\sum$ siloxane (mean $105.7 \pm 67.9 \mu \mathrm{g} / \mathrm{g}$, median $96.9 \mu \mathrm{g} / \mathrm{g}$ ), followed by pacifiers (mean $79.2 \pm 129.8 \mu \mathrm{g} / \mathrm{g}$, median $33.9 \mu \mathrm{g} / \mathrm{g}$ ), soft rubber toys (mean $9.75 \pm 13.2 \mu \mathrm{g} / \mathrm{g}$, median $8.67 \mu \mathrm{g} /$ $\mathrm{g}$ ), hard toys (mean $0.029 \pm 0.040 \mu \mathrm{g} / \mathrm{g}$, median $0.018 \mu \mathrm{g} / \mathrm{g}$ ). Higher concentrations of siloxanes in pacifiers and teethers might be because these two children silicone-containing products consist of silicon rubber primarily. Methylsiloxanes, as the major material for synthetizing silicon, may exist in silicon rubber as residual starting materials, whereas hard toys and soft rubber toys may be composed of other materials such as latex and plastics, in which a small quantity of siloxanes were used as additives.

The total concentrations of cyclic methylsiloxanes ( $\sum \mathrm{CMS}$ ), including D4-D6, in pacifiers, teethers, soft rubber toys, and hard toys ranged from 0.193 to $185.5 \mu \mathrm{g} / \mathrm{g}$ ( median $=2.82 \mu \mathrm{g} / \mathrm{g}$; mean $=10.0 \pm 31.0 \mu \mathrm{g} /$ g), 0.042 to $28.3 \mu \mathrm{g} / \mathrm{g}$ ( median $=6.05 \mu \mathrm{g} / \mathrm{g}$; mean $=8.53 \pm 7.31 \mu \mathrm{g} / \mathrm{g}$ ), $0.090-11.4 \mu \mathrm{g} / \mathrm{g}$ (median $=0.276 \mu \mathrm{g} / \mathrm{g} ;$ mean $=1.73 \pm 3.16 \mu \mathrm{g} / \mathrm{g})$ and less than LOQ to $0.047 \mu \mathrm{g} / \mathrm{g}$ (median $=0.001 \mu \mathrm{g} / \mathrm{g}$; mean $=0.005 \pm$ $0.010 \mu \mathrm{g} / \mathrm{g}$ ), respectively. Compared to cyclic methylsiloxanes, the total concentrations of linear methylsiloxanes ( $\sum$ LMS), including L5L16, were four to ten times higher in all categories of children silicone-containing products. $\sum$ LMS (L5-L16) in pacifiers, teethers, soft rubber toys, and hard toys ranged from 4.86 to $570.9 \mu \mathrm{g} / \mathrm{g}$ (median $=$ $27.4 \mu \mathrm{g} / \mathrm{g} ;$ mean $=68.9 \pm 104.7 \mu \mathrm{g} / \mathrm{g}), 2.85-225.0 \mu \mathrm{g} / \mathrm{g}($ median $=$ $85.5 \mu \mathrm{g} / \mathrm{g} ;$ mean $=91.7 \pm 65.5 \mu \mathrm{g} / \mathrm{g}), 2.36-8.03 \mu \mathrm{g} / \mathrm{g}$ (median $=$ $7.68 \mu \mathrm{g} / \mathrm{g}$; mean $=8.03 \pm 12.4 \mu \mathrm{g} / \mathrm{g}$ ), and less than LOQ to $0.112 \mu \mathrm{g} / \mathrm{g}$ ( median $=0.015 \mu \mathrm{g} / \mathrm{g}$; mean $=0.024 \pm 0.031 \mu \mathrm{g} / \mathrm{g}$ ), respectively. The distribution percentage of $\sum$ CMS and $\sum$ LMS in the total methylsiloxanes concentrations ( $\sum$ siloxane) for different types of children silicone-containing products are shown in Fig. 1. $\sum$ LMS in hard toys, pacifiers, teethers, and soft rubber toys accounted for, on average $82 \%, 87 \%, 91 \%$, and $82 \%$, respectively, of the total methylsiloxanes ( $\sum$ siloxane). The results indicated that linear siloxanes were the predominant methylsiloxanes in the studied children silicone-containing products. $\sum$ CMS in pacifier/nipples in the previous study (Horii and Kannan, 2008) should be higher than those in our study due to their reported higher median concentrations of individual homologues of cyclic siloxanes. Meanwhile, Horii and Kannan (2008) showed that $\sum$ LMS in pacifier $/$ nipples had lower concentrations (median $=11 \mu \mathrm{g} / \mathrm{g}$; mean $=$ $14 \mu \mathrm{g} / \mathrm{g}$ ) than those in our study, indicating that the in contrast to our study, cyclic but not linear siloxanes were the predominant methylsiloxanes in the pacifier/nipples in their study.

\subsection{Migration of methylsiloxanes from children products to artificial saliva}

Methylsiloxanes in children silicone-containing products are likely to result in potential mouthing exposure, which has not been reported until now. In order to evaluate mouthing exposure, we firstly investigated the leaching of methylsiloxanes from children products in artificial saliva via a $10 \mathrm{~h}$ immersion test. Table 2 provides an overview of the migration concentration of methylsiloxanes from children products to artificial saliva. Except for L6, other 14 methylsiloxanes were detected (mean $=0.001 \pm 0.008-0.770 \pm 2.60 \mathrm{ng} / \mathrm{mL}$ ) in saliva for children products, with detection frequencies ranging from 4 to $46 \%$. The results indicated that methylsiloxanes could migrate from children products to saliva during use, which may expose children and infants to methylsiloxanes.

For pacifiers, methylsiloxanes (D4-D6, L5, and L7-L16) were positively identified in artificial saliva with mean concentrations in the range of $0.004 \pm 0.013-1.21 \pm 1.93 \mathrm{ng} / \mathrm{mL}$ ( $\mathrm{df}=11-68 \%$ ). For teethers, methylsiloxanes (D4-D6, L7-L16) were detected in artificial saliva with mean concentrations ranging from $0.070 \pm 0.162-1.13 \pm 1.46 \mathrm{ng} / \mathrm{mL}$ ( $\mathrm{df}=31-69 \%$ ). For soft rubber toys, the detection frequencies of methylsiloxanes (D4-D6, L7-L16) ranged from 14 to $41 \%$ in artificial saliva, which was lower than those of teethers and pacifiers, with mean concentrations ranging from $0.040 \pm 0.149-0.467 \pm 0.779 \mathrm{ng} / \mathrm{mL}$. It

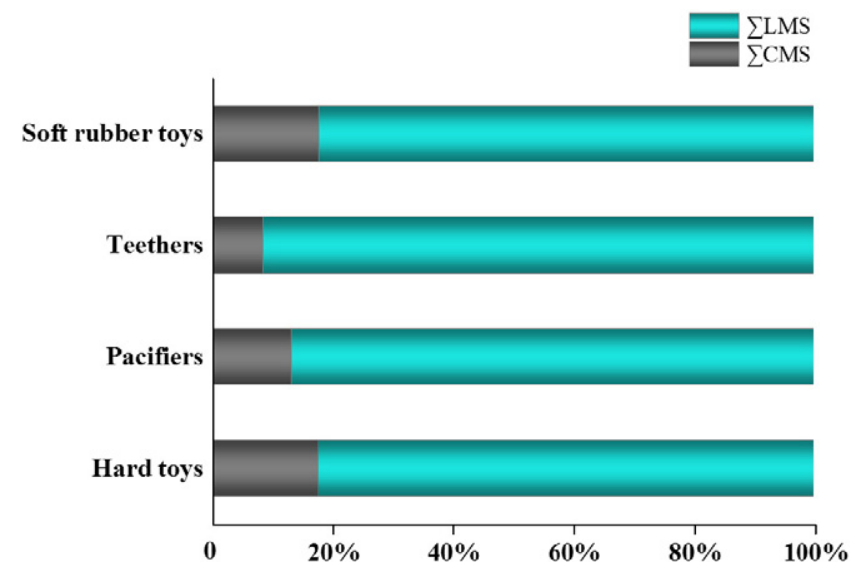

Fig. 1. Distribution profiles of total cyclic siloxanes (D4-D6), twelve linear siloxanes (L4L16) in children products. 
Table 2

Concentrations (ng/mL; max, min, median and mean) and detection frequency (\%) of methylsiloxanes in artificial saliva.

\begin{tabular}{|c|c|c|c|c|c|c|c|c|c|c|c|c|c|c|c|c|}
\hline & & D4 & D5 & D6 & L5 & L6 & L7 & L8 & L9 & L10 & L11 & L12 & L13 & L14 & L15 & L16 \\
\hline \multirow[t]{6}{*}{ Pacifiers } & Mean $^{\mathrm{a}}$ & 0.179 & 0.800 & 1.48 & 0.004 & $<0.01$ & 0.100 & 0.080 & 0.140 & 0.161 & 0.241 & 0.150 & 0.179 & 0.360 & 1.21 & 0.602 \\
\hline & SD & 0.487 & 1.68 & 3.97 & 0.013 & & 0.226 & 0.338 & 0.475 & 0.340 & 0.546 & 0.521 & 0.461 & 1.04 & 1.93 & 1.23 \\
\hline & Min & $<0.02$ & $<0.02$ & $<0.03$ & $<0.02$ & $<0.01$ & $<0.02$ & $<0.05$ & $<0.03$ & $<0.01$ & $<0.01$ & $<0.01$ & $<0.05$ & $<0.01$ & $<0.04$ & $<0.06$ \\
\hline & Median & $<0.02$ & 0.038 & 0.077 & $<0.02$ & $<0.01$ & 0.031 & $<0.05$ & $<0.03$ & 0.032 & 0.021 & 0.016 & 0.054 & 0.022 & 0.302 & 0.07 \\
\hline & Max & 2.76 & 8.00 & 16.3 & 0.072 & $<0.01$ & 1.05 & 1.96 & 2.66 & 1.46 & 3.20 & 3.02 & 2.40 & 6.01 & 7.33 & 6.08 \\
\hline & df (\%) & 49 & 57 & 59 & 11 & 0 & 51 & 22 & 24 & 62 & 54 & 59 & 62 & 57 & 68 & 51 \\
\hline \multirow[t]{6}{*}{ Teethers } & Mean & 0.250 & 1.13 & 1.03 & $<0.02$ & $<0.01$ & 0.170 & 0.070 & 0.400 & 0.100 & 0.120 & 0.102 & 0.321 & 0.200 & 0.801 & 0.580 \\
\hline & SD & 0.578 & 1.46 & 1.24 & & & 0.308 & 0.162 & 1.14 & 0.316 & 0.239 & 0.196 & 0.390 & 0.467 & 2.01 & 1.44 \\
\hline & Min & $<0.02$ & $<0.02$ & $<0.03$ & $<0.02$ & $<0.01$ & $<0.02$ & $<0.05$ & $<0.03$ & $<0.01$ & $<0.01$ & $<0.01$ & $<0.05$ & $<0.01$ & $<0.04$ & $<0.06$ \\
\hline & Median & $<0.02$ & 0.450 & 0.440 & $<0.02$ & $<0.01$ & 0.021 & $<0.05$ & $<0.03$ & $<0.01$ & $<0.01$ & $<0.01$ & 0.214 & 0.014 & 0.066 & 0.072 \\
\hline & Max & 2.32 & 4.33 & 3.68 & $<0.02$ & $<0.01$ & 1.07 & 0.593 & 4.67 & 1.25 & 0.780 & 0.693 & 1.11 & 1.44 & 7.02 & 5.33 \\
\hline & df $(\%)$ & 44 & 69 & 69 & 0 & 0 & 50 & 44 & 38 & 44 & 44 & 31 & 63 & 50 & 63 & 50 \\
\hline \multirow[t]{6}{*}{ Soft rubber toys } & Mean & 0.101 & 0.102 & 0.082 & $<0.02$ & $<0.01$ & 0.120 & 0.145 & 0.044 & 0.103 & 0.040 & 0.068 & 0.070 & 0.168 & 0.467 & 0.212 \\
\hline & SD & 0.273 & 0.282 & 0.276 & & & 0.352 & 0.481 & 0.094 & 0.428 & 0.149 & 0.134 & 0.110 & 0.449 & 0.779 & 1.78 \\
\hline & Min & $<0.02$ & $<0.02$ & $<0.03$ & $<0.02$ & $<0.01$ & $<0.02$ & $<0.05$ & $<0.03$ & $<0.01$ & $<0.01$ & $<0.01$ & $<0.05$ & $<0.01$ & $<0.04$ & $<0.06$ \\
\hline & Median & $<0.02$ & $<0.02$ & $<0.03$ & $<0.02$ & $<0.01$ & $<0.02$ & $<0.05$ & $<0.03$ & $<0.01$ & $<0.01$ & $<0.01$ & $<0.05$ & $<0.01$ & $<0.04$ & $<0.06$ \\
\hline & Max & 1.11 & 1.16 & 1.24 & $<0.02$ & $<0.01$ & 1.21 & 2.10 & 0.32 & 2.01 & 0.700 & 0.510 & 0.310 & 1.61 & 2.45 & 2.05 \\
\hline & df (\%) & 36 & 36 & 14 & 0 & 0 & 23 & 23 & 23 & 23 & 18 & 32 & 36 & 36 & 41 & 27 \\
\hline \multirow[t]{6}{*}{ All products } & Mean $^{a}$ & 0.136 & 0.523 & 0.770 & 0.001 & $<0.01$ & 0.097 & 0.075 & 0.133 & 0.103 & 0.059 & 0.092 & 0.139 & 0.212 & 0.713 & 0.380 \\
\hline & SD & 0.410 & 1.28 & 2.60 & 0.008 & & 0.256 & 0.320 & 0.559 & 0.324 & 0.168 & 0.342 & 0.346 & 0.719 & 1.56 & 1.02 \\
\hline & Min & $<0.02$ & $<0.02$ & $<0.03$ & $<0.02$ & $<0.01$ & $<0.02$ & $<0.05$ & $<0.03$ & $<0.01$ & $<0.01$ & $<0.01$ & $<0.05$ & $<0.01$ & $<0.04$ & $<0.06$ \\
\hline & Median & $<0.02$ & $<0.02$ & $<0.03$ & $<0.02$ & $<0.01$ & $<0.02$ & $<0.05$ & $<0.03$ & $<0.01$ & $<0.01$ & $<0.01$ & $<0.05$ & $<0.01$ & $<0.04$ & $<0.06$ \\
\hline & Max & 2.76 & 8.00 & 16.3 & 0.072 & $<0.01$ & 1.21 & 2.10 & 4.67 & 2.01 & 1.07 & 3.02 & 2.40 & 6.01 & 7.33 & 6.08 \\
\hline & $\mathrm{df}(\%)$ & 35 & 42 & 38 & 4 & 0 & 34 & 21 & 21 & 37 & 33 & 36 & 43 & 39 & 46 & 35 \\
\hline
\end{tabular}

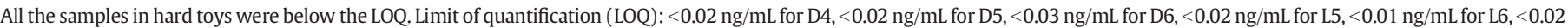

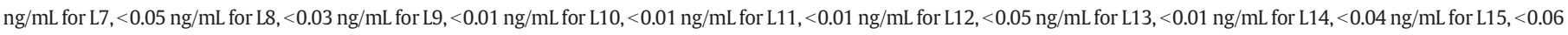
$\mathrm{ng} / \mathrm{mL}$ for $\mathrm{L} 16$.

a Concentrations below LOQ were calculatld with $\mathrm{f} \times \mathrm{LOQ}$ with $\mathrm{f}$ being the fraction of samples above LOQ.

was noted that no methylsiloxane was found in artificial saliva of hard toys, which might be the result of too low concentrations of methylsiloxanes in these products. Generally, solid-liquid phases partition of chemicals with low concentrations approximately fitted linear (Henry) adsorption isotherms (Karickhoff et al., 1979), hence we evaluated the migration capacity of methylsiloxanes by the following equation:

$M R=C_{S} / C_{p}$

where $M R$ is the migration ratio of methylsiloxanes from children products to artificial saliva; $C_{s}$ is the concentrations of methylsiloxanes in artificial saliva; $C_{p}$ is the methylsiloxanes concentrations in children products. Only concentrations of methylsiloxanes greater than the LOQ were used to calculate the migration capacity.

$\mathrm{L} 5(\mathrm{df}=4 \%)$ and $\mathrm{L} 6(\mathrm{df}=0)$ showed too low detection frequencies in artificial saliva extracts for all the children silicone-containing products, and their migration ratios were not calculated. The mean migration ratios of cyclic methylsiloxanes were $0.241 \pm 0.09 \%$ for $\mathrm{D} 4,0.173 \pm$ $0.07 \%$ for D5 and $0.135 \pm 0.04 \%$ for D6, whereas the mean migration ratio of linear methylsiloxanes were $0.142 \pm 0.04 \%$ for $\mathrm{L} 7,0.129 \pm$ $0.04 \%$ for L8, $0.121 \pm 0.03 \%$ for L9, $0.124 \pm 0.04 \%$ for L10, $0.112 \pm$ $0.03 \%$ for $\mathrm{L} 11,0.117 \pm 0.04 \%$ for $\mathrm{L} 12,0.103 \pm 0.03 \%$ for $\mathrm{L} 13,0.108 \pm$ $0.04 \%$ for L14, $0.087 \pm 0.03 \%$ for L15, $0.076 \pm 0.03 \%$ for L16 (Fig. 2, Table S3). The results indicated that the migration capacities of linear methylsiloxanes, except for L7, were lower than those of cyclic methylsiloxanes. Perhaps due to their high molecular weights and structural similarities with polymeric dimethylsiloxanes materials in children products, linear methylsiloxanes (L8-L16) had stronger sorption properties than cyclic methylsiloxanes in children products. Meanwhile, for both cyclic and linear, except for L10, L12 and L14, congeneric compounds, the migration capacity decreased with the increase of the number of $\mathrm{Si}-\mathrm{O}$ bonds. The difference in migration behaviors among homologues of methylsiloxanes could be partially explained by the organic carbon/water distribution coefficient $\left(K_{O C}\right)$. Methylsiloxanes with higher molecular weight exhibit higher $K_{O C}$ and are more likely to be adsorbed into the children products, lowering their migration capacity into artificial saliva. It should be noted that, the migration of methylsiloxanes from children silicone-containing products to saliva is a complex process, which is influenced by many factors (Zhang et al., 2012). Therefore, further studies are required to fully understand their migration process from children silicone-containing products to saliva.

Meanwhile, a time dependent migration test of methylsiloxanes in artificial saliva was performed. We selected 45 samples that included pacifiers $(n=30)$ and teethers $(n=15)$ because of their higher detection frequencies of methylsiloxanes. The samples were immersed in artificial saliva for the following time intervals: 5, 20, 40, 60, 120, 240, $600 \mathrm{~min}$. Samples were analyzed in triplicates at each interval time. For pacifiers, the concentrations of total cyclic siloxanes (D4-D6) in artificial saliva were $4.34-11.12 \mathrm{ng} / \mathrm{mL}$, whereas the total linear methylsiloxanes (L5-L16) were 7.97-16.34 ng/mL. For teethers, the concentrations of total cyclic siloxanes (D4-D6) in artificial saliva were 2.78-6.15 ng/mL, whereas the total linear methylsiloxanes (L5L16) were $2.57-9.06 \mathrm{ng} / \mathrm{mL}$. As indicated in Fig. 3a and b, as the time

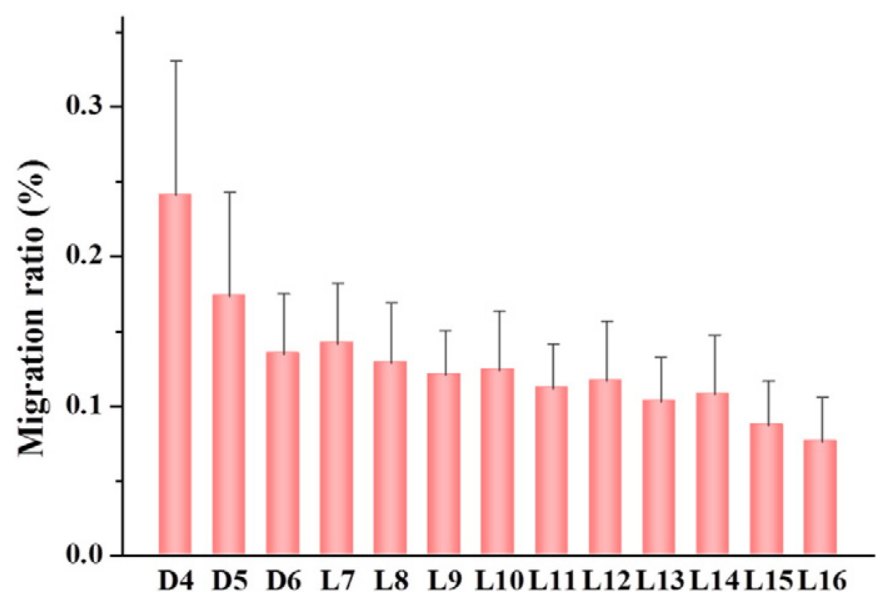

Fig. 2. Migration ratio of methyl siloxanes (D4-D6, L7-L16) from children products to artificial saliva. 


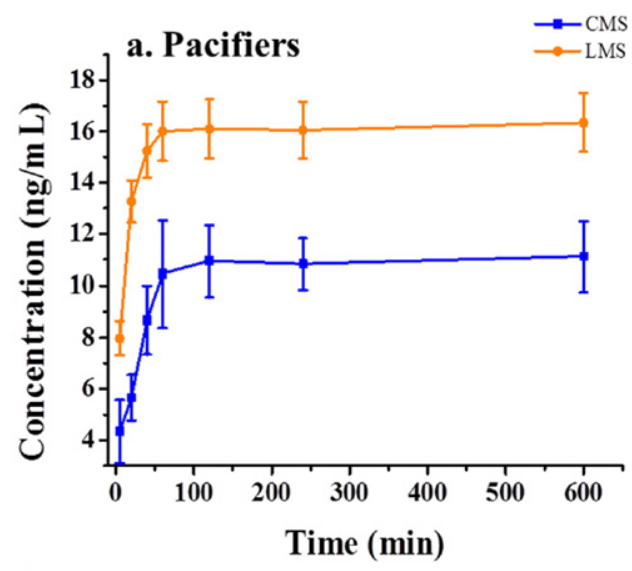

a) Migration concentrations of pacifiers in different time

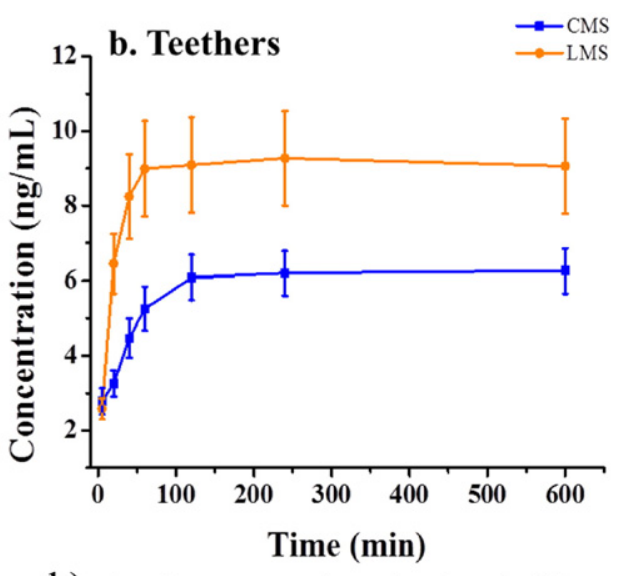

b) Migration concentrations of teethers in different time

Fig. 3. a. Migration concentrations of pacifiers in different time. b. Migration concentrations of teethers in different time.

increased, the concentration of cyclic and linear methylsiloxanes in artificial saliva gradually increased for both pacifiers and teethers. For cyclic methylsiloxanes, they reached the highest concentrations after 120 min of immersion, whereas for linear methylsiloxanes, they reached the highest concentrations after $60 \mathrm{~min}$ of immersion. Later, the concentrations of both cyclic and linear methylsiloxanes leveled off. Linear methylsiloxanes reached the highest concentrations first due to their greater solubility as compared to cyclic methylsiloxanes.

\subsection{Children exposure assessment}

We estimated the daily mouthing methylsiloxanes exposure of children during normal use of silicone-containing products. Because no migration concentration was detected in hard toys, we selected pacifiers, teethers, and soft rubber toys to assess the daily exposure. Likewise, the oral exposure as a result of the hand-to-mouth contact behaviors was not considered.

The mouthing exposure (nanogram per kilogram body weight per day) was calculated by the following equation.

$E_{\text {mouth }}=C_{\text {product }} \times W_{\text {product }} \times M F \times$ Bio $/ B W$

where $C_{\text {product }}$ is the methylsiloxane concentration in children products; $W$ is the weight of the entire product; $B W$ is body weight; Bio is bioavailability fraction. Due to the lack of directly measured specific Bio for siloxane in children products, we used 1.0 as the value for all studied siloxanes. $M F$ (migration fraction) was fraction of methylsiloxanes in the product that can migrate to saliva, and could be calculated by the following equation (Franzen et al., 2016):

$M F=\left(C_{\text {saliva }} \times V_{\text {saliva }} \times t\right) /\left(C_{\text {product }} \times W_{\text {product }}\right)$

where $C_{\text {saliva }}$ was the methylsiloxanes concentration in artificial saliva, which was the migration concentrations from children products to artificial saliva in our present study; $t$ is daily contact time for children products. For pacifiers, the contact time reported in previous study for children in 3-36 months ranged from 43.2-81.6 min/day, whereas for teethers/soft rubber toys the contact time ranged from 2.4$7.2 \mathrm{~min} /$ day [ Greene, 2002; U.S. Environmental Protection Agency (EPA), 2011 ]. Thus, we selected $C_{\text {saliva }}$ after 60 min immersion for pacifiers and $C_{\text {saliva }}$ after $5 \mathrm{~min}$ immersion for teethers/soft rubber toys to calculate mouthing exposure. $V_{\text {saliva }}$ is the volume of saliva per min. For children in 3-6 months and 6-12 months, $V_{\text {saliva }}$ is $0.47 \mathrm{~mL} / \mathrm{min}$, for children in 12-24 months and $24-36$ months, $V_{\text {saliva }}$ is $0.63 \mathrm{~mL} /$ min (Dezan et al., 2002). BW is body weight of exposed children (kg). Body weight and exposure time is selected according to relative parameters as provided by U.S. Environmental Protection Agency (EPA), 2011. (Table S4, Table S5)

There would be some uncertainties in the calculation of methylsiloxane mouthing exposure as following reasons: 1) Because of the limited amount of samples, the residual concentration of methylsiloxanes in our study would be different with the real concentration in Chinese market. 2) To some content, the leaching capacities of methylsiloxanes during chewing behaviors of children are different from those during artificial saliva leaching test in our study. 3) Fraction of methylsiloxanes in the nipples and teethers that can migrate to saliva (migration factor) would decrease with both continued use of these products and washing with water (Franzen et al., 2016). Therefore, the mouthing exposure reported in the present study was "conservative exposure".

Overall, the conservative mouthing exposure levels to methylsiloxanes from children's silicone products were summarized in Table 3. The exposure to $\sum$ CMS in the studied age groups ranged from $6.87-18.05 \mathrm{ng} / \mathrm{kg}$ bw-day and $0.44-2.29 \mathrm{ng} / \mathrm{kg}$ bw-day via pacifiers and teethers/soft rubber toys, respectively, whereas the exposure for $\sum$ LMS ranged from $7.89-20.74 \mathrm{ng} / \mathrm{kg}$ bw-day and $0.41-2.12 \mathrm{ng} /$ $\mathrm{kg}$ bw-day via pacifiers and teethers/soft rubber toys, respectively. Due to more frequent use and longer contact times, the total methylsiloxanes exposure via pacifiers were 1-2 orders of magnitudes higher than the exposure via teethers/soft rubber toys. In addition,

Table 3

Calculated children exposure levels (ng/kg bw-day) $\sum$ cyclic methylsiloxanes ( $\sum$ CMS) and $\sum$ linear methylsiloxanes ( $\sum$ LMS) in different exposure pathways.

\begin{tabular}{|c|c|c|c|c|c|c|c|c|}
\hline & \multicolumn{2}{|c|}{ Mouth exposure (pacifiers) } & \multicolumn{2}{|c|}{$\begin{array}{l}\text { Mouth exposure } \\
\text { (teethers/soft rubber toys) }\end{array}$} & \multicolumn{2}{|c|}{ Inhalation exposure } & \multicolumn{2}{|c|}{ Dust ingestion exposure } \\
\hline & $\sum \mathrm{CMS}$ & $\overline{\sum \text { LMS }}$ & $\sum \mathrm{CMS}$ & $\overline{\sum \mathrm{LMS}}$ & $\sum \mathrm{CMS}$ & $\overline{\sum \text { LMS }}$ & $\sum \mathrm{CMS}$ & $\sum \mathrm{LMS}$ \\
\hline 3-6 months & 18.05 & 20.74 & 2.29 & 2.12 & 293.6 & - & 0.44 & 4.18 \\
\hline $6-12$ months & 14.52 & 12.76 & 1.74 & 1.61 & 311.1 & - & 0.36 & 3.36 \\
\hline $12-24$ months & 12.01 & 9.55 & 1.05 & 0.97 & 371.9 & - & 0.29 & 2.71 \\
\hline 24-36 months & 6.87 & 7.89 & 0.44 & 0.41 & 341.8 & - & 0.24 & 2.24 \\
\hline
\end{tabular}


Table 3 also showed that children in different ages have different exposure levels: children 3-6 months and 6-12 months had slightly higher mouthing exposures than the other two age groups for pacifiers as well as for teethers/soft rubber toys.

Besides mouthing exposure, inhalation, dust ingestion and dermal contact are also pathways of human exposure to methylsiloxanes and other volatile compounds (Little et al., 2012; Lu et al., 2010; Tran et al., 2015; Tran and Kannan, 2015). Inhalation exposure occurs as a result of methylsiloxanes emission from personal care products (PCPs), and any other products containing methylsiloxanes. The inhalation exposure was calculated according to the following equation:

$E_{\text {inhala }}=C_{\text {air }} \cdot V_{\text {air }} \cdot F_{\text {uptake }} / B W$

where $C_{\text {air }}$ is the mean concentrations $\left(5.3 \mu \mathrm{g} / \mathrm{m}^{3}\right)$ of cyclic methylsiloxanes in residential houses from China referred to one previous study (Xu et al., 2012). Due to the lack of linear methylsiloxanes in indoor air in China, $E_{\text {inhala }}$ only includes the exposure to cyclic methylsiloxanes. $V_{\text {air }}$ represents volume of inhalation for children in different age groups $\left(\mathrm{m}^{3} / \mathrm{day} ; 4.1\right.$ for children in 36 months; 5.4 for children in 6 - 12 months; 8.0 for children in 12 24 months; 9.5 for children in 24-36 months) as detailed by the U.S. Environmental Protection Agency (EPA), 2011. $F_{\text {uptake }}$ is the uptake fraction of the compound. $F_{\text {uptake }}$ for D4 and D5 was about 0.1 due to their low blood/air partition. Here, we selected 0.1 as inhalation $F_{\text {uptake }}$ for cyclic methylsiloxanes (D4-D6). The inhalation exposure for children in different ages are summarized in Table 3. In addition, Tran and Kannan (2015) reported that the daily inhalation exposure level of total siloxanes for infants and toddlers were 3.18 and $1.59 \mu \mathrm{g} / \mathrm{kg}$ bw-day for toddlers.

Children may have a tendency to ingest dust in their daily life. Ingestion of dust is a potential route of exposure to methylsiloxanes. Lu et al. (2010) determined the occurrence of cyclic and linear siloxanes in indoor dust from China, and total siloxanes exposure $\left(E_{\text {dust, }}\right.$, Table 3$)$ for children via dust ingestion was calculated to be $2.48-4.62 \mathrm{ng} / \mathrm{kg}$ bwday for toddlers (1.5-3 years). In addition, dermal contact was one of the most important exposure pathways of methylsiloxanes (Lu et al., 2011). However, due to lack of detailed information on daily usage rates of personal care products in children (ages 3-36 months), dermal exposure rates of methysliloxanes were not calculated in the present study. Overall, methylsiloxanes mouthing exposure associated with children products were 1-2 order of magnitudes lower than the sum of children's daily inhalation exposure and dust ingestion exposure in the indoor environment. This result indicated that although children (ages 3-36 months) come into direct contact with organosilicone products, this exposure pathway is not predominant for children because of low migration concentrations for methylsiloxanes and shorter contact times. It should be noted that methylsiloxanes with low molecular weights in children silicone-containing products would be released to indoor air, dust, airborne particles and indoor surfaces, hence the exposure via inhalation, dust ingestion and dermal absorption arising from these products should be considered in future studies.

\section{Conclusions}

Children silicone-containing products analyzed in present study contained varying concentrations of methylsiloxanes (D4-D6, L5L16). Linear methylsiloxanes were predominant in these four types of children products. Methylsiloxanes in children silicone-containing products are likely to result in potential mouthing exposure. Although methylsiloxanes, as the impurities of polydimethylsiloxane, distributed widely in children silicone products, exposure arising from directly mouthing these products may not be the dominated pathway for children exposure of methylsiloxanes.

\section{Acknowledgments}

This work was supported by the National Natural Science Foundation of China $(21537004,21407159,21321004)$ and the Strategic Priority Research Program of the Chinese Academy of Sciences (XDB14010201).

\section{Appendix A. Supplementary data}

Supplementary data to this article can be found online at http://dx. doi.org/10.1016/j.envint.2017.01.022.

\section{References}

Allami, A., Mohammadi, N., Shahrokhi, R., 2010. Temperature recording sites in infants, children, and adults. Iran. Red Crescent Med. J. 12 (4), 413-418.

Bletsou, A.A., Asimakopoulos, A.G., Stasinakis, A.S., Thomaidis, N.S., Kannan, K., 2013. Mass loading and fate of linear and cyclic siloxanes in a wastewater treatment plant in Greece. Environ. Sci. Technol. 47, 1824-1832.

Buser, A.M., Kierkegaard, A., Bogdal, C., MacLeod, M., Scheringer, M., Hungerbühler, K., 2013. Concentrations in ambient air and emissions of cyclic volatile methylsiloxanes in Zurich, Switzerland. Environ. Sci. Technol. 47 (13), 7045-7051.

Clewell, H.J., Gentry, P.R., Covington, T.R., Sarangapani, R., Teeguarden, J.G., 2004. Evaluation of the potential impact of age and gender-specific pharmacokinetic differences on tissue dosimetry. Toxicol. Sci. 79, 381-393.

Dezan, C.C., Nicolau, J., Souza, D.N., Walter, L.R.F., 2002. Flow rate, amylase activity, and protein and sialic acid concentrations of saliva from children aged 18, 30 and 42 months attending a baby clinic. Arch. Oral Biol. 423-427.

Dudzina, T., von Goetz, N., Bogdal, C., Biesterbos, J.W., 2014. Concentrations of cyclic volatile methylsiloxanes in European cosmetics and personal care products: prerequisite for human and environmental exposure assessment. Environ. Int. 62, 86-94.

Franzen, A., Landingham, C.V., Greence, T., Plotzke, K., Gentry, R., 2016. A global human health risk assessment for Decamethylcyclopentasiloxane (D5). Regul. Toxicol. Pharmacol. 74, 25-43.

Ginsberg, G., Hattis, D., Sonawame, B., Russ, A., Banati, P., Kozlak, M., Smolenski, S., Goble, R., 2002. Evaluation of child/adult pharmacokinetic differences from a database derived from the therapeutic drug literature. Toxicol. Sci. 66, 185-200.

Greene, M.A., 2002. Mouthing Times for Children From the Observational Study. U.S. Consumer Product Safety Commission, Bethesda, MD.

Horii, Y., Kannan, K., 2008. Survey of organosilicone compounds, including cyclic and linear siloxanes, in personal care and household products. Arch. Environ. Contam. Toxicol. 55, 701-710.

Hunter, M.J., Hyde, J.F., Warrick, E.L., Fletcher, H.J., 1946. Organo-silicon polymers. the cyclic dimethyl siloxanes. J. Am. Chem. Soc. 68 (4), 667-672.

Jia, H., Zhang, Z., Wang, C., Hong, W., Sun, Y., Li, Y., 2015. Trophic transfer of methyl siloxanes in the marine food web from coastal area of Northern China. 49, 2833-2840.

Karickhoff, S.W., Brown, D.S., Scott, T.A., 1979. Sorption of hydrophobic pollutants on natural sediments. Water Res. 13, 241-248.

Kusu, F., Ohe, K., Takamura, K., 1998. Electrochim. Acta 43 (1873)

Lee, S., Moon, H.B., Song, G.J., Ra, K., Lee, W.C., Kannan, K., 2014. A nationwide survey and emission estimates of cyclic and linear siloxanes through sludge from wastewater treatment plants in Korea. Sci. Total Environ. 497, 106-112.

Little, J.C., Weschler, C.J., Nazaroff, W.W., Liu, Z., Cohen Hubal, E.A., 2012. Rapid methods to estimate potential exposure to semivolatile organic compounds in the indoor environment. Environ. Sci. Technol. 46, 11171-11178.

Lu, Y., Yuan, T., Yun, S., Wang, W., Wu, Q., Kannan, K., 2010. Occurrence of cyclic and linear siloxanes in indoor dust from China, and implications for human exposures. Environ. Sci. Technol. 44, 6081-6087.

Lu, Y., Yuan, T., Wang, W., Kannan, K., 2011. Concentration and assessment of exposure to siloxanes and syntheticmusks in personal care products from China. Environ. Pollut. 159, 3522-3528.

McGoldrick, D., Chan, C., Drouillard, K., Keir, M., Clark, M., Backus, S., 2014. Concentrations and trophic magnification of cyclic siloxanes in aquatic biota from the Western Basin of Lake Erie, Canada. Environ. Pollut. 186, 141-148.

McLachlan, M.S., Kierkegaard, A., Hansen, K.M., van Egmond, R., Christensen, J.H., Skioth, C.A., 2010. Concentrations and fate of decamethylcyclopentasiloxane (D5) in the atmosphere. Environ. Sci. Technol. 44, 5365-5370.

Niessner, G. Klampfl, C.W., 2000. Direct comparison of solid-phase extraction and solidphase microextraction for the gas chromatographic determination of dibenzylamine in artificial saliva leachates from baby bottle teats. Anal. Chim. Acta 414, 133-140.

Pieri, F., Katsoyiannis, A., Martellini, T. Hughes, D., Jones, K.C., Cincinelli, A., 2013. Occurrence of linear and cyclic volatile methyl siloxanes in indoor air samples (UK and Italy) and their isotopic characterization. Environ. Int. 59, 363-371.

Sanchis, J., Cabrerizo, A., Galban-Malagon, C., Barcelo, D., Farre, M., Dachs, J., 2015. Unexpected occurrence of volatile dimethylsiloxanes in Antarctic soils, vegetation, phytoplankton, and krill. Environ. Sci. Technol. 49 (7), 4415-4424.

Sparham, C., Van Egmond, R., O'Connor, S., Hastie, C., Whelan, M., Kanda, R., 2008. Determination of decamethylcyclopentasiloxane in river water and final effluent by headspace gas chromatography/mass spectrometry. J. Chromatogr. A 1212, 124-129.

Tran, T.M., Kannan, K., 2015. Occurrence of cyclic and linear siloxanes in indoor air from Albany, New York, USA, and its implications for inhalation exposure. Sci. Total Environ. $511,138-144$. 
Tran, T.M., Abualnaja, K.O., Asimakopoulos, A.G., Covaci, A., Bondi, G., Boris, J.R., Kumosani, T.A., Malarvannan, G., Minh, T.B., Moon, H.B., Nakata, H., Ravindra, K.S., Kannan, K., 2015. A survey of cyclic and linear siloxanes in indoor dust and their implications for human exposures in twelve countries. Environ. Int. 78, 39-44.

U.S. Environmental Protection Agency (EPA), 2011. Exposure Factors Handbook. 2011 ed. National Center for Environmental Assessment, Washington, DC (EPA/600/R-09/ 052F).

Wang, D.G., Steer, H., Tait, T., Williams, Z., Pacepavicius, G., Young, T., Ng, T., Smyth, S.A Kinsman, L., Alaee, M., 2013. Concentration of cyclic volatile methylsiloxanes in biosolid amended soil, influent, effluent, receiving water, and sediment of wastewater treatment plants in Canada. Chemosphere 93, 766-773.

Warner, N.A., Evenset, A., Christensen, G., Gabrielsen, G.W., Borga, K., Leknes, H., 2010. Volatile siloxanes in the European Arctic: assessment of sources and spatial distribution. Environ. Sci. Technol. 44, 7705-7710.
Xu, L., Shi, Y., Wang, T., Dong, Z., Su, W., Cai, Y., 2012. Methyl siloxanes in environmental matrices around a siloxane production facility, and their distribution and elimination in plasma of exposed population. Environ. Sci. Technol. 46, 11718-11726.

Xu, L., Shi, Y., Liu, N., Cai, Y., 2015. Methyl siloxanes in environmental matrices and human plasma/fat from both general industries and residential areas in China. Sci. Total Environ. 505, 454-463.

Zhang, Z., Qi, H., Ren, N., Li, Y., Gao, D., Kannan, K., 2011. Survey of cyclic and linear siloxanes in sediment from Songhua river and in sewage sludge from wastewater treatment plants, Northeastern China. Arch. Environ. Contam. Toxicol. 60, 204-211.

Zhang, K., Wong, J.W., Begley, T.H., Hayward, D.G., Limm, W., 2012. Determination of siloxanes in silicone products and potential migration to milk, formula and liquid simulants. Food Addi. Contam. Part A 29 (8), 1311-1321. 